\title{
Supplier Evaluation in Book Retail Industry using Analytical Hierarchy Process (AHP)
}

\author{
Pratik Singhal ${ }^{1}$, Ramkrishna Manatkar ${ }^{2}$ \\ ${ }^{1}$ Symbiosis Institute of Operations Management, Symbiosis International (Deemed University), Pune, India
}

\begin{abstract}
Since the introduction of E-commerce in book retail in India, it has become important for the vendors and store owners in book retail industry to source their products from the correct suppliers, in order to compete with E-commerce giants. This paper focuses on proposing a structured model for evaluating suppliers in Book retail industry in India, using Analytic Hierarchy Process (AHP). This proposed model is evolved using evidence from an observed study in Tier 2 city of India. The model takes into account the various factors which are considered by the vendors in Book Retail Industry while placing their orders of books with different suppliers. The criteria considered for this model includes, Discount Offered (Cost), credit terms, return policy, delivery time, Genuineness (Quality) of product. However, Discount Offered and Genuineness of product are two important factors out of all. This proposed model can be used by the vendors to further select the best supplier for sourcing their product.
\end{abstract}

Keywords

Analytical Hierarchy process, Multi criteria Decision Making, Supplier selection and evaluation, Vendors

Article Received: 10 August 2020, Revised: 25 October 2020, Accepted: 18 November 2020

\section{Introduction}

India's book retail Industry which proves to be sixth largest in the world and second largest of the English language has an estimated worth of INR 231 billion and expected to grow up to INR 739 billion by 2020. The "compound annual growth rate (CAGR)" of 19.3 percent for the book retail industry in the next 5 years was estimated in Nielsen India Book Report 2015. (The Economic Times, 2015)

Till 2013, the book retail industry usually incorporated unorganized sector and the organized retail sector accounted only seven percent out of the total. (Business Standard, 2013) The industry was more driven through small retail shops with a strong supply chain around the country. However, the scenario changed after E-commerce giants like Flipkart, Amazon stepped into the market and the businesses of small vendors was impacted to core. The book retail industry has also faced tough competition after the introduction of E-books and readily available online reading content on various apps like Kindle. The concept of E-books enabled the customer to have virtual reading experience at cheaper rates, in comparison to physical books. But, for the vendors it proved to be a nightmare, as this industry operates with a model of carrying high inventory as per the customer's demand and for which they require more and more space along with incurring high inventory carrying costs. According to the vendors, they have seen a steep decline of approximately 20 percent in their sales over a period of 3 years.

The only solution in order to compete with Ecommerce giants and E-book market, which these vendors of retail book shops anticipated was to have better sourcing strategies and offer the books at best prices in order to serve and retain their customers. The book retail industry has also been struggling hard due to the counterfeiting of the books in order to have higher margins for the suppliers, but on the contrary leaving the customers in dark. So, the audacity of having genuine products for their customers comes as an additional challenge for the vendors.

\section{Literature Review}

The main goal of "supplier selection" is to distinguish amongst the various suppliers with the most elevated potential for addressing a vendor's need "consistently and at an acceptable cost". "Selection" is a broad analogy of suppliers utilizing a typical arrangement of standards and measures. In any case, the degree of detail utilized for looking at capable suppliers may change contingent upon a vendor's needs. The general objective of selection is to single out "high potential suppliers". (Kahraman, Cebeci, \& Ulukan, 2003) 
Multiple work in terms of research has been done in the field of supplier selections and has been discussed in literature. (Weber, Current , \& Benton, 1991) has reconsidered various researches on supplier selection in JIT environment (Just in Time), he also quoted that supplier selection process recognizes multiple parameters. (Timmerman, 1987), (Sharma \& Yadav, 2016), (Agarwal, Sahai, Mishra, Bag, \& Singh, 2011) have also quoted that "vendor(supplier) selection problem is a type of multi criteria decision making problem". Usually, "supplier selection problem" exploits more than one parameter as an explanation for the "selection of the preferred supplier". (Mendoza, Santiago, \& Ravindran, 2008) (Motwani, Larson, \& Ahuja, 1998) (Astanti, Mbolla, \& Ai, 2020) (Olhager \& Selldin, 2004)

As discussed by (Liu \& Hai, 2005) diverse firms or enterprise might administer diverse criteria respecting "supplier selection". Based on the preceding researches it can be derived that "the very first step in a supplier selection process starts with election of criterion that have to be adopted to find the best supplier." Hence, for a vendor, to select amongst various suppliers it becomes important to have different criteria in place to evaluate its supplier. (Astanti, Mbolla, \& Ai, 2020)

The various parameters which are accounted in this research with reference to supplier evaluation in the book retail industry by vendors are as follows:

$\begin{aligned} \text { i. } & \text { Discounts offered } \\ \text { ii. } & \text { Delivery } \\ \text { iii. } & \text { Credit terms } \\ \text { iv. } & \text { Return Policy } \\ \text { v. } & \text { Genuineness (Quality) }\end{aligned}$

\subsection{Discounts offered}

The reduction in price that is done on the Maximum Retail Price (MRP) of the book for the vendor from its supplier is known as discount. The reduced price which is paid by the vendor after discount to the supplier also acts as a cost for the vendor. According to (Nickels, McHugh, \& S.M., 2008), for sustaining into a business it is important to reduce the cost so as to generate more profits. Cost has been given the due importance in the previous researches as well. (Mirabi, Ghomi, \& Jolai, 2010) (Paksoy,
Özceylan, \& Weber, 2013) (Choi \& Chang, 2006) (Azizi \& Modarres, 2010)

\subsection{Delivery}

The time which is taken by the supplier to deliver the order to the vendor includes the time which it takes to process the order along with the time taken in its transportation from supplier's place to vendor's place. This factors also takes into account the supplier's flexibility, geographical location and order processing time taken at supplier's end. It is important to minimize the time taken for the delivery so as to meet the customer's demand at the right time. (Gnanasekaran, Velappan, \& Manimaran, 2006) (Abel, Cortés Ríos, Pato, Keane, \& Fernandes, 2020) (Gonzalez, Quesada, \& Mora Monge, 2004) (Azizi \& Modarres, 2010) (Asamoah, Annan, \& Nyarko, 2012)

\subsection{Credit Terms}

The payment terms which are laid down by the suppliers for its vendors, includes mode, duration of the payment and credit limit. Some suppliers allow their vendor with a credit period of three months whereas some may extent it up to a year. The credit limit which is decided by the supplier is dependent on the frequency and amount of orders that a vendor has done in past. It may vary between INR 2 Lacs to INR 10 Lacs. This factor plays a significant role as the business model of the retail book store industry is dependent on carrying huge inventories and concepts of Just in Time are nearly impossible to practice due to geographical distances of the suppliers. Credit Terms has been considered as significant criteria in supplier selection process in the previously conducted researches as well. (Asamoah, Annan, \& Nyarko, 2012) (Mirabi, Ghomi, \& Jolai, 2010) (Louw, Hall, \& Pradhan, 2019)

\subsection{Return Policy}

The return policy signifies the rules that are laid down by the supplier to manage the return process of his books by the vendor which are unwanted or are outdated and were previously bought by him in anticipation of demand but eventually has remain unsold due to reasons like fall in demand. This factor comes into play with the books those have been updated or revised in their latest edition. The return policy may allow no return or maximum of a yearlong return period for the vendors. According to (Janakiraman, Syrdal, \& Freling, 2016), the purchasing criteria of the 
supplier is largely impacted by the return policies in place, which holds true for this industry as well. (Kaushik, Kumar, Gupta, \& Dixit, 2020) (Pennarola, Caporarello, \& Magni, 2019) (Ahsan \& Rahman, 2016) (Chen \& Chen, Competing with customer returns policies, 2016) (Chen \& Bell, 2012)

2.5. Genuineness (Quality)

Book industry has been hit hard due to cloning or illegal printing of duplicate books in the market in order to have unlawful increase in the profits. As per the reports, the vendors are offered twice discounted rates for selling duplicate books into the market but to maintain the goodwill in the market some vendors prefer to source and sell only genuine products. (News18, 2020)

To make sure the genuineness of the product, they prefer the trusted and reliable suppliers only. The trustworthiness, reputation of the supplier, Probability of receiving faulty products, Past experience with suppliers are some of the factors which are available in the previous researches too and will hold good in this industry as well. (Asamoah, Annan, \& Nyarko, 2012); (Nayak, Sinha, \& Guin, 2011); (Çebi \& Bayraktar, 2003) (Li, Wong, \& Kwong, 2013)

After finalizing the criteria, the next step is to select the "decision models" in the final choice phase of supplier evaluation. As per the previously conducted researches, there are five decision model which are: "Linear Weighing Model", "Total Cost Ownership Model", (Degraeve, Labro, \& Roodhooft, 2000), "Mathematical Programming" (Ghodsypour \& O'Brien, 1998); (Talluri \& Narasimhan, 2003); (Choy, Lee, \& Lo, 2003), "Statistical Models, Artificial Intelligence (AI) - based models" (Choy, Lee, \& Lo, 2003). "Analytical Hierarchy Process (AHP)" and "Analytic Network Process (ANP)" are part of the "linear weighting model", as reported by (De Boer, Labro, \& Morlacchi, 2001). A few techniques can be treated as optimizing technique where so as to utilize those technologies, the quantitative parameters are required. However, while working on supplier selection problems the vendor has to deal with both, the qualitative data such as Genuineness (quality) of the book as well as quantitative data such as discount offered or the delivery time taken by the supplier. To deal with this issue, it is suitable to use Analytic Hierarchy Process as a decision model for supplier evaluation.

"Analytical Hierarchy Process (AHP)" is a structured technique which is used for formulating, interpreting and evaluating the complex business decisions using mathematics and psychology as the basis. This process was initially developed by Thomas L Saaty during 1970s, who later collaborated with Ernest Forman to come up with Expert Choice in 1983, since then this process has been refined multiple times. Analytical Hierarchy Process (AHP) expresses an authentic approach for quantifying the weights of decision criteria. Singular individual encounters are used to gauge the overall extents of elements through pair-wise comparisons. Instead of endorsing a "right" choice, the AHP enables "decision makers" to discover an alternative that best suits their objective and their understanding of the issue. (Saaty, The Analytic heirarchy Process, 1980) ; (Saaty, 1994)

\section{Research Methodology}

The Analytical Hierarchy Process model of this research is shown in Figure 1. The primary objective of this research was to evaluate and select the best supplier for a vendor in book retail industry. The criteria defined for conducting the research were Discount offered, Delivery, Return Policy, Payment Terms, Genuineness (Quality). The alternatives considered in this research were three suppliers, namely, Supplier 1, Supplier 2, Supplier 3. The AHP is used to solve "MultiCriteria Decision-Making" problems in supplier selection. 


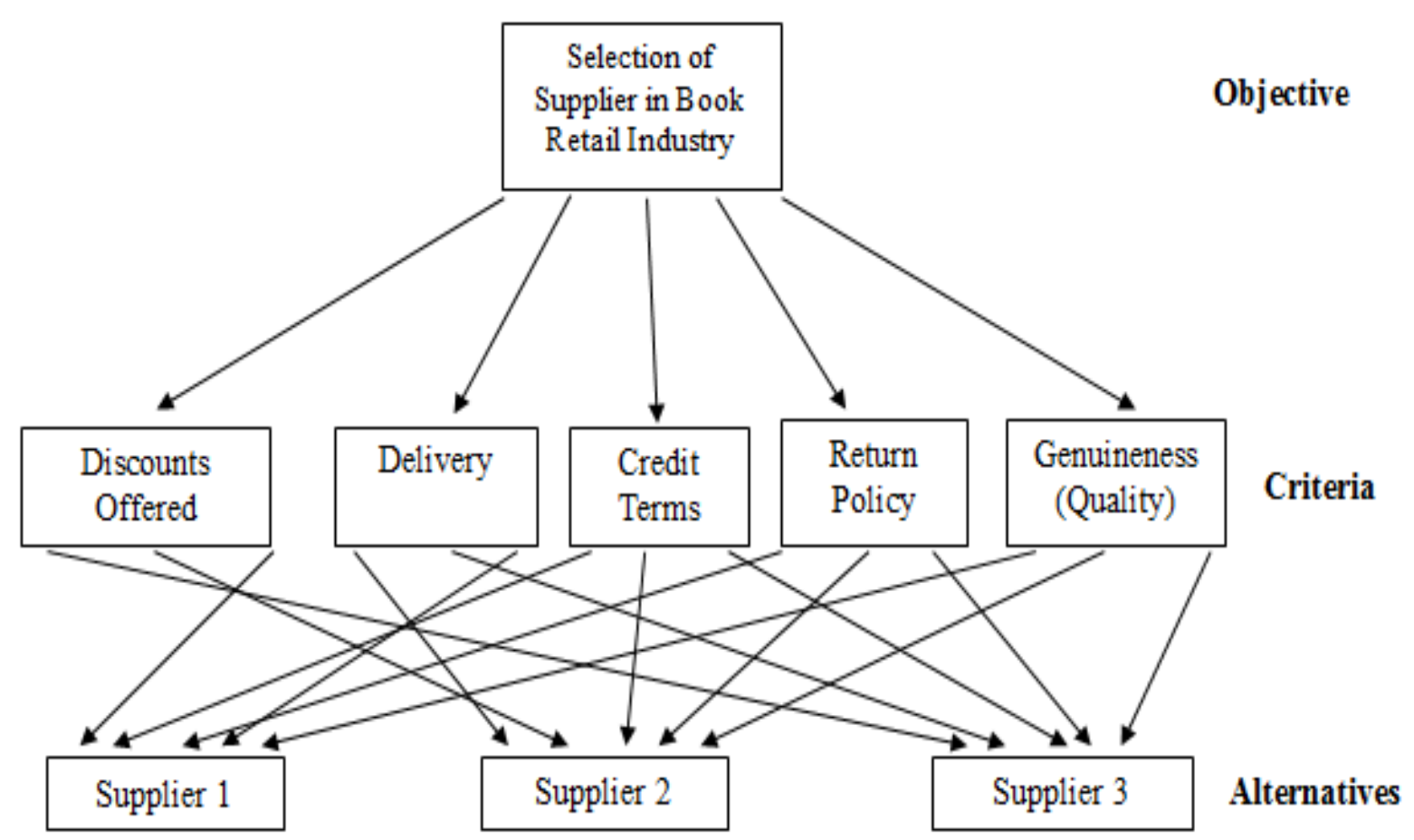

Figure 1: Typical AHP Model for Selection of Supplier Book Retail Industry

to different criteria while placing their orders with

Analytic Hierarchy Process in book retail industry was implemented by surveying book retail vendors across a Tier 2 city of India. The survey was focused on collecting responses on the comparative importance which the vendors gives their suppliers. The relative significance between two parameters(criteria) is computed on a numerical scale of 1 to 9 , as shown in the table 1 , where it was presumed that $\mathrm{m}^{\text {th }}$ criterion is equally or more significant than $\mathrm{n}^{\text {th }}$ criterion.

Table 1:Table of relative scoring in AHP

\begin{tabular}{|l|l|}
\hline Value of amn & Interpretation \\
\hline 1 & m and $\mathrm{n}$ are equally significant \\
\hline 3 & $\mathrm{~m}$ is slightly more significant than $\mathrm{n}$ \\
\hline 5 & $\mathrm{~m}$ is more significant than $\mathrm{n}$ \\
\hline 7 & $\mathrm{~m}$ is strongly more significant than $\mathrm{n}$ \\
\hline 9 & m is absolutely more significant than $\mathrm{n}$ \\
\hline $2,4,6,8$ & Intermediate values \\
\hline $1 / 3,1 / 5,1 / 7,1 / 9$ & Inverted values (Reciprocals) \\
\hline
\end{tabular}

3.1. Forming Pairwise Comparison Matrix Among criteria

The responses collected were later averaged out and a "Pairwise comparison matrix" between the different criteria in place was formed. The sum for each criterion was calculated, as shown in Table 2. (Saaty, 1980)

Table 2:Pairwise Comparison Matrix Among Criteria

\begin{tabular}{|l|l|l|l|l|l|}
\hline Criteria & $\begin{array}{l}\text { Discounts } \\
\text { Offered }\end{array}$ & Delivery & Credit terms & $\begin{array}{l}\text { Return } \\
\text { Policy }\end{array}$ & Genuineness \\
\hline $\begin{array}{l}\text { Discounts } \\
\text { Offered }\end{array}$ & 1 & 5 & 6 & 7 & 1 \\
\hline Delivery & $1 / 5$ & 1 & 4 & 3 & $1 / 6$ \\
\hline Credit terms & $1 / 6$ & $1 / 4$ & 1 & 2 & $1 / 7$ \\
\hline Return Policy & $1 / 7$ & $1 / 3$ & $1 / 2$ & 1 & $1 / 4$ \\
\hline Genuineness & 1 & 6 & 7 & 4 & 1 \\
\hline
\end{tabular}




\begin{tabular}{|l|l|l|l|l|l|}
\hline Sum & 2.51 & 12.58 & 18.50 & 17.00 & 2.56 \\
\hline
\end{tabular}

comparison matrix by making equal to 1 , and the

3.2. Normalizing comparison matrix and calculating Criteria Weight

After the pairwise comparison matrix (A) was

formed, it was important to normalize the pairwise

value obtained in each row was average out to obtain Criteria weights (w) as shown in table 3. (Saaty, 1994)

Table 3: Normalized Pairwise Comparison Matrix

\begin{tabular}{|l|l|l|l|l|l|l|}
\hline Criteria & $\begin{array}{l}\text { Discounts } \\
\text { Offered }\end{array}$ & Delivery & Credit terms & Return Policy & Genuineness & $\begin{array}{l}\text { Criteria } \\
\text { Weight }\end{array}$ \\
\hline $\begin{array}{l}\text { Discounts } \\
\text { Offered }\end{array}$ & $\begin{array}{l}1 / 2.51= \\
0.3985\end{array}$ & $\begin{array}{l}5 / 12.58= \\
0.3974\end{array}$ & $6 / 18.50=0.3243$ & $7 / 17=0.4118$ & 0.3907 & 0.3845 \\
\hline Delivery & 0.0797 & 0.0795 & 0.2162 & 0.1765 & 0.0651 & 0.1234 \\
\hline Credit terms & 0.0664 & 0.0199 & 0.0541 & 0.1176 & 0.0558 & 0.0628 \\
\hline $\begin{array}{l}\text { Return } \\
\text { Policy }\end{array}$ & 0.0569 & 0.0265 & 0.0270 & 0.0588 & 0.0977 & 0.0534 \\
\hline Genuineness & 0.3985 & 0.4768 & 0.3784 & 0.2353 & 0.3907 & 0.3759 \\
\hline
\end{tabular}

3.3. Checking Consistency of the Criteria Weight The next stage is to calculate $\lambda$, so as to lead to "Consistency Index (CI) and Consistency Ratio (CR)". The calculation of Criteria Weight is done by determining "eigenvector" and "eigenvalue". "Eigenvector is the proportion of the weight of each parameter while eigenvalue denotes the multiplication and eigenvector with the eigenvector value." Mathematically, the expression of "eigenvector (w) and eigenvalue $(\lambda)$ " can be formulated as follows: (Astanti, Mbolla, \& Ai, 2020) (Saaty, 1994)

$\mathrm{A} \cdot \mathrm{w}=\lambda \cdot \mathrm{w}$

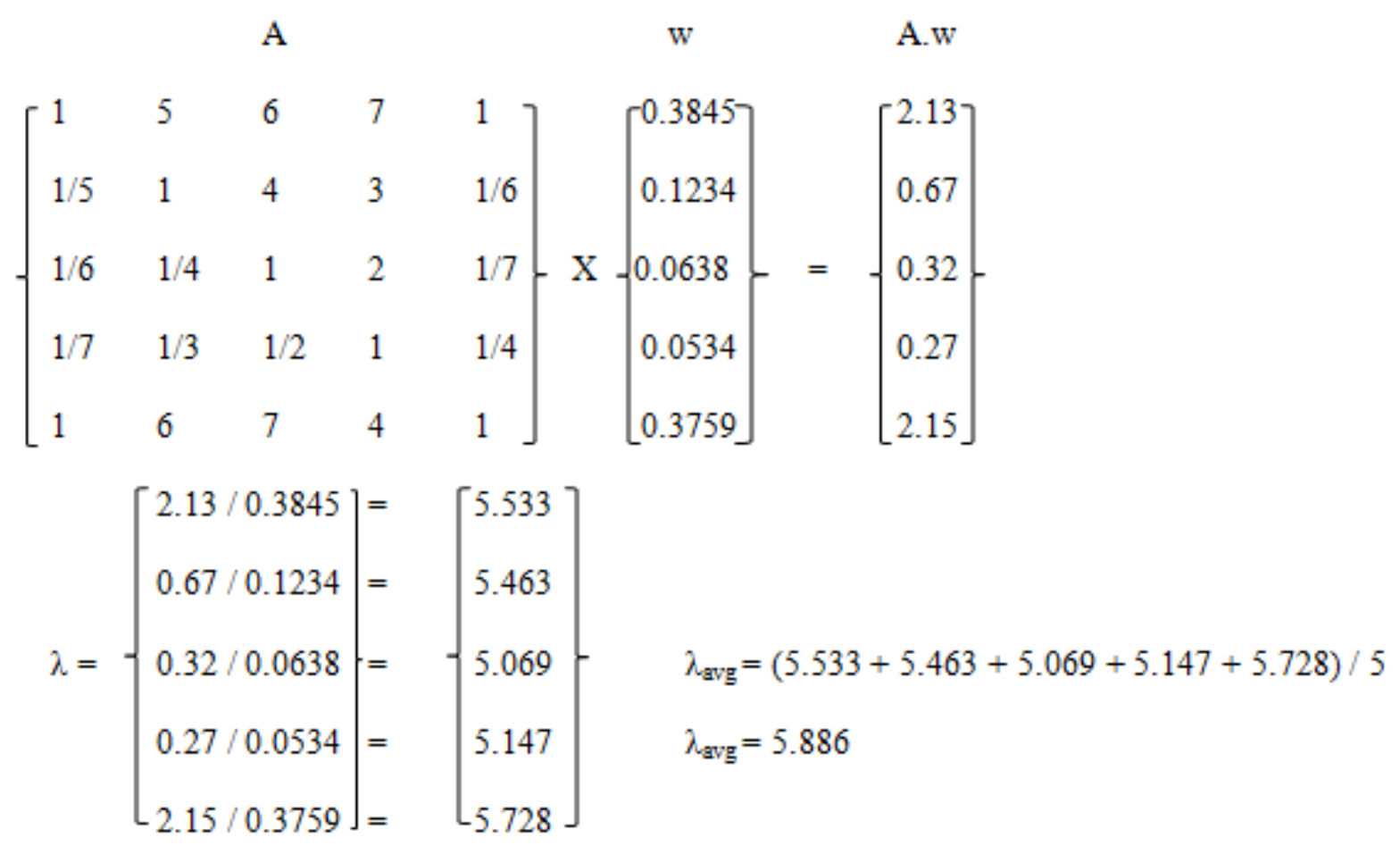

2020) Consistency Ratio value can be derived by dividing the value of "Consistency Index (CI)" to the value of "Random Consistency Index (RI)". Value of "Consistency Index" is derived from the equation:

$$
C I=\frac{\lambda_{\text {avg }}-n}{n-1} \quad \mathrm{CR}=\mathrm{CI} / \mathrm{RI}
$$


where,

$\mathrm{CI} \quad=$ Consistency Index

Consistency Ratio

$\lambda_{\text {avg }}=$ Eigenvalue

Random Index $\mathrm{n} \quad=$ Matrix order, here $\mathrm{n}=5$

The value of "Random Index" can be obtained by Table 4.

Table 4: Random Consistency Index (RI) (Saaty, 1994)

\begin{tabular}{|l|l|l|l|l|l|l|l|l|l|l|}
\hline Matrix Order (n) & 1 & 2 & 3 & 4 & 5 & 6 & 7 & 8 & 9 & 10 \\
\hline $\begin{array}{l}\text { Random Consistency } \\
\text { Index (RI) }\end{array}$ & 0 & 0 & 0.52 & 0.89 & 1.12 & 1.25 & 1.35 & 1.40 & 1.45 & 1.49 \\
\hline
\end{tabular}

For this case, since $\lambda_{\text {avg }}=5.3886$ and $\mathrm{n}$ is equal to 5 , therefore, Consistency Index is equal to 0.10 . From Table 4, it is known that Random Consistency Index is equal to 1.12, the respective value of $\mathrm{n}$. Therefore, Consistency Ratio is equal to 0.08674 . Hence, the "comparison is consistent". It can be seen that weight criteria for Discounts offered and Genuineness (Quality) is maximum, $38.45 \%$ and $37.59 \%$ respectively. Hence, these 2 are considered as most important factors while considering any supplier. Whereas, Delivery, Credit Terms, Return Policy has weight criteria of $12.34 \%, 6.28 \%, 5.34 \%$ respectively.
3.4. Formation of Pairwise matrix among suppliers

Now, to further select the best supplier, one of the vendors was asked to compare three alternatives (suppliers) based on the criteria on a numerical scale of 1-9, as shown in Table 1.

On a similar basis five (for each criteria) "pair wise comparison matrix" comparing different suppliers were formed for three suppliers represented as S - [1] or S1, S - [2] or S2, S - [3] or $\mathrm{S} 3$ respectively.

Table 5: Pair Wise Comparison Matrix Among Suppliers

\begin{tabular}{|c|c|c|c|c|c|c|c|c|c|c|c|}
\hline $\begin{array}{l}\text { Discounts } \\
\text { Offered }\end{array}$ & $\mathrm{S} 1$ & $\mathrm{~S} 2$ & S3 & Delivery & $\mathrm{S} 1$ & $\mathrm{~S} 2$ & S3 & $\begin{array}{l}\text { Credit } \\
\text { Terms }\end{array}$ & $\mathrm{S} 1$ & $\mathrm{~S} 2$ & S3 \\
\hline$S-[1]$ & 1 & 1 & 4 & $S-[1]$ & 1 & $1 / 3$ & 4 & $S-[1]$ & 1 & 1 & 5 \\
\hline$S-[2]$ & 1 & 1 & 5 & $S-[2]$ & 3 & 1 & 6 & $S-[2]$ & 1 & 1 & 5 \\
\hline$S-[3]$ & $1 / 4$ & $1 / 5$ & 1 & $S-[3]$ & $1 / 4$ & $1 / 6$ & 1 & $S-[3]$ & $1 / 5$ & $1 / 5$ & 1 \\
\hline $\begin{array}{l}\text { Return } \\
\text { Policy }\end{array}$ & S1 & $\mathrm{S} 2$ & S3 & Genuineness & S1 & $\mathrm{S} 2$ & S3 & & & & \\
\hline$S-[1]$ & 1 & $1 / 4$ & 2 & $S-[1]$ & 1 & 7 & 3 & & & & \\
\hline$S-[2]$ & 4 & 1 & 6 & $S-[2]$ & $1 / 7$ & 1 & $1 / 3$ & & & & \\
\hline$S-[3]$ & $1 / 2$ & $1 / 6$ & 1 & $S-[3]$ & $1 / 3$ & 3 & 1 & & & & \\
\hline
\end{tabular}

\subsection{Calculating Priority Weights}

calculated similar to method followed in Now, these matrixes were normalized and respective local priorities for alternatives were

Table 6: Local Priorities Among the Supplier

\begin{tabular}{|l|l|l|l|l|l|l|l|l|l|}
\hline $\begin{array}{l}\text { Discounts } \\
\text { offered }\end{array}$ & $\begin{array}{l}\text { Priority } \\
\text { Weight }\end{array}$ & Delivery & $\begin{array}{l}\text { Priority } \\
\text { Weight }\end{array}$ & $\begin{array}{l}\text { Credit } \\
\text { Terms }\end{array}$ & $\begin{array}{l}\text { Priority } \\
\text { Weight }\end{array}$ & $\begin{array}{l}\text { Return } \\
\text { Policy }\end{array}$ & $\begin{array}{l}\text { Priority } \\
\text { Weight }\end{array}$ & Genuineness & $\begin{array}{l}\text { Priority } \\
\text { Weight }\end{array}$ \\
\hline $\mathrm{S}-[1]$ & 0.43 & $\mathrm{~S}-[1]$ & 0.27 & $\mathrm{~S}-[1]$ & 0.45 & $\mathrm{~S}-[1]$ & 0.19 & $\mathrm{~S}-[1]$ & 0.67 \\
\hline $\mathrm{S}-[2]$ & 0.47 & $\mathrm{~S}-[2]$ & 0.64 & $\mathrm{~S}-[2]$ & 0.45 & $\mathrm{~S}-[2]$ & 0.7 & $\mathrm{~S}-[2]$ & 0.09 \\
\hline $\mathrm{S}-[3]$ & 0.1 & $\mathrm{~S}-[3]$ & 0.09 & $\mathrm{~S}-[3]$ & 0.09 & $\mathrm{~S}-[3]$ & 0.11 & $\mathrm{~S}-[3]$ & 0.24 \\
\hline
\end{tabular}

\subsection{Calculating Overall Priorities}

For calculating overall priorities, Priority weights will be multiplied with their respective criteria weights and then it will be summed to obtain calculating criteria weights and shown in Table 6

overall priorities. Once the overall priority is obtained, the selection of suppliers can be done by ranking the supplier with maximum value of overall priority. 
Table 7:Supplier Selection based on Overall Priority and Rank

\begin{tabular}{|l|l|l|l|l|l|l|l|}
\hline Criteria & Discounts offered & Delivery & $\begin{array}{l}\text { Credit } \\
\text { Terms }\end{array}$ & $\begin{array}{l}\text { Return } \\
\text { Policy }\end{array}$ & Genuineness & Overall & \\
\cline { 1 - 1 } $\begin{array}{l}\text { Criteria } \\
\text { Weights }\end{array}$ & 0.38 & 0.12 & 0.06 & 0.05 & 0.37 & $\begin{array}{l}\text { Priority } \\
\text { Rank }\end{array}$ \\
\hline Supplier 1 & $0.43 * 0.38=0.16$ & 0.03 & 0.03 & 0.01 & 0.25 & 0.48 & I \\
\hline Supplier 2 & $0.47 * 0.38=0.18$ & 0.08 & 0.03 & 0.04 & 0.03 & 0.36 & II \\
\hline Supplier 3 & $0.10 * 0.38=0.04$ & 0.01 & 0.01 & 0.01 & 0.09 & 0.16 & III \\
\hline
\end{tabular}

Expert Systems with Applications.

After calculating the Overall Priority, it was found that Supplier 1 (S - [1]) had $48 \%$ chance of selection and ranked $1^{\text {st }}$, whereas Supplier $2(\mathrm{~S}-$ [2]) had $36 \%$ chance of selection and was ranked $2^{\text {nd }}$ and similarly Supplier $3(S-[3])$ had only 16 percent chance of selection.

\section{Conclusion}

The supplier evaluation and selection in book retail industry can be done using Analytic Hierarchy Process (AHP) which consists of five criteria namely Discount offered, Delivery, Credit Terms, Return Policy, Genuineness as shown in Figure 1. Out of these five criteria, Discount Offered and Genuineness plays a major role in selection of supplier, which is shown in Table 3. Finally, vendor can calculate the overall priority and rank their "supplier as the basis of their procurement and sourcing process" to select the suppliers from given set of alternatives, which is shown in Table 7.

\section{Future Scope of Improvement}

This research was conducted among the book retail vendors in Tier 2 city of India, similar researches can be done in the Tier 1 cities and other Tier 2 cities of India as well, which will provide greater number of book retail vendors to participate in the research. Conduction of similar researches with different geographical locations will help in refinement of the proposed model, as geographical location of supplier can change their decisions. Further, researchers can include sub criteria in their research as well, which will facilitate to have better credence of the proposed model.

\section{References}

[1] Abel, E., Cortés Ríos, J., Pato, N., Keane, J., \& Fernandes, A. (2020). Targeted Evidence Collection for Uncertain Supplier Selection.
[2] Agarwal, P., Sahai, M., Mishra, V., Bag, M., \& Singh, V. (2011). A review of multicriteria decision making techniques for supplier evaluation and selection. International Journal of Industrial Engineering Computations, 801-810.

[3] Ahsan, K., \& Rahman, S. (2016). An investigation into critical service determinants of customer to business (C2B) type product returns in retail firms. International Journal of Physical Distribution and Logistics Management, Volume 46, Issue 6-7, 606-633.

[4] Asamoah, D., Annan, J., \& Nyarko, S. (2012). AHP approach for supplier evaluation and selection in a pharmaceutical manufacturing firm in Ghana. International Journal of Business and Management, Volume 7, Issue 10, 49-62.

[5] Astanti, R. D., Mbolla, S. E., \& Ai, T. J. (2020). Raw material supplier selection in a glove manufacturing: Application of AHP and fuzzy AHP. Decision Science Letters 9, 291-312.

[6] Azizi, M., \& Modarres, M. (. (2010). A decision model to select facial tissue raw material: A case from Iran. OR Insight, Volume 23, Issue 4, 207-232.

[7] Çebi, F., \& Bayraktar, D. (2003). An integrated approach for supplier selection. Logistics Information Management, Volume 16, Issue 6, 395-400.

[8] Chen, J., \& Bell, P. (2012). Implementing market segmentation using full-refund and no-refund customer returns policies in a dual-channel supply chain structure. 
International Journal of Production Economics, Volume 136, Issue 1, 56-66.

[9] Chen, J., \& Chen, B. (2016). Competing with customer returns policies. International Journal of Production Research,Volume 54, Issue 7, 2093-2107.

[10] Choi, J. H., \& Chang, Y. S. (2006). A twophased semantic optimization modeling approach on supplier selection in eProcurement. Expert Systems with Applications, 137-144.

[11] Choy, K. L., Lee, W., \& Lo, V. (2003). Design of a case based intelligent supplier relationship management system-the integration of supplier rating system and product coding system. Expert Systems with Applications, Volume 25, Issue 1, 87-100.

[12] De Boer, L., Labro, E., \& Morlacchi, P. (2001). A review of methods supporting supplier selection. European Journal of Purchasing \& Supply Management, Volume 7, Issue 2, 75-89.

[13] Degraeve, Z., Labro, E., \& Roodhooft, F. (2000). An evaluation of vendor selection models from a total cost of ownership perspective. European Journal of Operational Research, Volume 125, Issue 1, 34-58.

[14] Ghodsypour, S. H., \& O'Brien, C. (1998). A decision support system for supplier selection using an integrated analytic hierarchy process and linear programming. International Journal of Production Economics, Volume 56, 199-212.

[15] Gnanasekaran, S., Velappan, S., \& Manimaran, P. (2006). Application of analytical hierarchy process in supplier selection: an automobile industry case study. South Asian Journal of Management, Volume 13, Issue 4, 89.

[16] Gonzalez, M. E., Quesada, G., \& Mora Monge, C. A. (2004). Determining the importance of the supplier selection process in manufacturing: a case study. International Journal of Physical Distribution \& Logistics Management, Volume 34, Issue 6, 492-504.

[17] Janakiraman, N., Syrdal, H. A., \& Freling,
R. (2016). The Effect of Return Policy Leniency on Consumer Purchase and Return Decisions: A Meta-analytic Review. Journal of Retailing, 226-235.

[18] Kahraman, C., Cebeci, U., \& Ulukan, Z. (2003). Multi-criteria supplier selection using fuzzy AHP. Logistics Information Management, Volume 16, Issue 6, 382-394.

[19] Kaushik, V., Kumar, A., Gupta, H., \& Dixit, G. (2020). A hybrid decision model for supplier selection in Online Fashion Retail (OFR). International Journal of Logistics Research and Applications, 1-25.

[20] Li, Z., Wong, W. K., \& Kwong, C. K. (2013). An integrated model of material supplier selection and order allocation using fuzzy extended AHP and multiobjective programming. Mathematical Problems in Engineering, Article ID 363718.

[21] Liu, F. H., \& Hai, H. L. (2005). The voting analytic hierarchy process method for selecting supplier. International Journal of Production Economics, 308-317.

[22] Louw, E., Hall, J., \& Pradhan, R. (2019). The Relationship Between Working Capital Management and Profitability: Evidence from South African Retail and Construction Firms. Global Business Review, 1-21.

[23] Mendoza, A., Santiago, E., \& Ravindran, A. (2008). A three-phase multicriteria method to the supplier selection problem. International Journal of Industrial Engineering, 195-210.

[24] Mirabi, M., Ghomi, F., \& Jolai, F. (2010). A Hybrid Electromagnetism-Like Algorithm for Supplier Selection in Make-to-Order Planning. Scientia Iranica Transaction E: Industrial Engineering, Volume 17, Issue 1, $1-11$.

[25] Motwani, J., Larson, L., \& Ahuja, S. (1998). Managing a global supply chain partnership. Logistics Information Management, 349-354.

[26] Nayak, J. K., Sinha, G., \& Guin, K. K. (2011). Impact of supplier management on a firm's performance. Desicion, Volume 38, Issue 1, 77-90. 
[27] News18. (2020). News18. Retrieved from www.news18.com:

https://www.news18.com/news/india/firagainst-bjp-leaders-son-for-printing-fakencert-books-worth-rs-35-crore-12-arrested2809709.html)

[28] Nickels, W., McHugh, J., \& S.M., M. (2008). Understanding Business, 8th Edition. Boston: McGraw-Hill Irwin.

[29] Olhager, J., \& Selldin, E. (2004). Supply chain management survey of Swedish manufacturing firms. International Journal of Production Economics, 353-361.

[30] Paksoy, T., Özceylan, E., \& Weber, G. W. (2013). Profit oriented supply chain network Optimization. Central European Journal of Operations Research, Volume 21, Issue 2, 455-478.

[31] Pennarola, F., Caporarello, L., \& Magni, M. (2019). Different Strategies for Different Channels: Influencing Behaviors in Product Return Policies for Consumer Goods. Lecture Notes in Information Systems and Organisation (pp. 247-259). Milan: Springer Heidelberg.

[32] Saaty, T. (1980). The Analytic heirarchy Process. New York, NY: McGraw-Hill.

[33] Saaty, T. (1994). Fundamental of Decision Making \& Priority Theory with the Analytical Hierarchy Process. Pittsburgh: RWS Publication.

[34] Sharma, M. K., \& Yadav, V. (2016). Multi-criteria supplier selection model using the analytic hierarchy process approach. Journal of Modelling in Management, 326354.

[35] Talluri, S., \& Narasimhan, R. (2003). Vendor evaluation with performance variability: A max-min approach. European Journal of Operational Research, Volume 146, Issue 3, 543-552.

[36] The Economic Times. (2015). Indian book market to touch Rs 739 billion by 2020: Survey. Retrieved from The Economic Times:

https://economictimes.indiatimes.com/indus try/media/entertainment/media/indian-book- market-to-touch-rs-739-billion-by-2020survey/articleshow/49996781.cms

[37] Timmerman, E. (1987). An approach to vendor performance evaluation. IEEE Engineering Management Review, 14-20.

[38] Weber, C. A., Current , J., \& Benton, W. (1991). Vendor selection criteria and methods. European Journal of Operation Research, 2-18. 